\title{
PENGARUH SANKSI PERPAJAKAN TERHADAP KEPATUHAN WAJIB PAJAK ORANG PRIBADI DI KANTOR PELAYANAN PAJAK PRATAMA MADIUN
}

\author{
Faradilla Savitri \\ Mahasiswa Prodi Pendidikan Ekonomi \\ dfara1626@gmail.com \\ Elva Nuraina \\ Dosen Prodi Pendidikan Akuntansi \\ elvanuraina@yahoo.co.id
}

\begin{abstract}
This study describes the effect of tax penalties to compliance of individual taxpayers in the Tax Office Primary Madiun. The method in this research is descriptive quantitative method while sampling technique in this research is incidental sampling technique that taxpayers in STO Madiun totaling 385 people. Collecting data using the method of observation, questionnaire, and documentation. In analyzing the data using simple linear regression analysis which includes validity, reliability, normality test, and to test the hypothesis proposed in this study using linear regression and test. The results showed that the effect on the Taxation Penalties Taxpayer Compliance. It is obtained from the value $t$ arithmetic amounted to 26.664 with a significance level of 0.000. Because 26.664> 1.966 and $0.000<0.05$ then Ho is rejected and Ha accepted.
\end{abstract}

Keywords: Sanctions Taxation, Taxpayer Compliance

\begin{abstract}
Abstrak
Penelitian ini memaparkan pengaruh sanksi perpajakan terhadap kepatuhan wajib pajak orang pribadi di Kantor Pelayanan Pajak Pratama Madiun. Metode dalam penelitian ini adalah metode Deskriptif kuantitatif sedangkan teknik pengambilan sampel dalam penelitian ini adalah teknik Sampling Insidental yaitu wajib pajak di KPP Pratama Madiun yang berjumlah 385 orang. Pengumpulan data menggunakan metode observasi, kuesioner, dan dokumentasi. Dalam menganalisis data menggunakan metode analisis regresi linier sederhana yang memuat uji validitas, uji reliabilitas, uji normalitas, dan untuk menguji hipotesis yang dikemukakan dalam penelitian ini menggunakan uji regresi linier dan uji t. Hasil penelitian menunjukkan bahwa Sanksi Perpajakan berpengaruh terhadap Kepatuhan Wajib Pajak. Hal ini diperoleh dari nilai t hitung adalah sebesar 26,664 dengan tingkat signifikansi 0,000. Karena 26,664 $>1,966$ dan 0,000 $<0,05$ maka Ho ditolak dan Ha diterima.
\end{abstract}

Kata Kunci: Sanksi Perpajakan, Kepatuhan Wajib Pajak

\section{PENDAHULUAN}

Pembangunan nasional adalah kegiatan yang berlangsung secara terus menerus dan berkesinambungan yang bertujuan untuk me- ningkatkan kesejahteraan rakyat baik materiil maupun spiritual. Untuk dapat merealisasikan tujuan tersebut perlu banyak memperhatikan masalah pembiayaan pembangunan. 
"Salah satu usaha untuk mewujudkan kemandirian suatu bangsa atau negara dalam pembiayaan pembangunan yaitu menggali sumber dana yang berasal dari dalam negeri berupa pajak. Pajak digunakan untuk membiayai pembangunan yang berguna bagi kepentingan bersama" (Waluyo, $2013: 02$ ).

"Pajak adalah kontribusi wajib kepada negara yang terutang oleh orang pribadi atau badan yang bersifat memaksa berdasarkan Undang-Undang, dengan tidak mendapatkan imbalan secara langsung dan digunakan untuk keperluan negara bagi sebesarbesarnya kemakmuran rakyat" (Diana dan Setiyawati, 2009:01).

Melihat Negara Indonesia kita dapat memahaminya melalui keadaan di sekitar kita seperti pendidikan, kesehatan, sarana umum, dll yang ada karena pajak yang disalurkan negara kita ke sektor-sektor tersebut. Permasalahan yang sering terjadi berkaitan dengan pungutan pajak ini yakni masih banyaknya masyarakat yang tidak mau memenuhi kewajiban pajaknya, atau dengan kata lain masih banyaknya tunggakan pajak. Tingkat kepatuhan wajib pajak untuk menunaikan kewajiban pembayaran pajaknya di Indonesia masih cukup rendah.

Tingkat kepatuhan wajib pajak dapat dipengaruhi beberapa faktor, diantaranya adalah pengenaan sanksi perpajakan, kualitas pelayanan, dan penerapan sistem adminisrasi perpajakan modern. Agar peraturan perpajakan dipatuhi, maka harus ada sanksi perpajakan bagi para pelanggarnya. Memberikan pelayanan yang baik kepada wajib pajak merupakan salah satu upaya dalam meningkatkan kepatuhan wajib pajak. Peningkatan kualitas dan kuantitas pelayanan wajib pajak diharapkan dapat menimbulkan kepuasan kepada wajib pajak sebagai pelanggan sehingga meningkatkan kepatuhan dalam bidang perpajakan.

Masalah kepatuhan pajak merupakan masalah klasik yang dihadapi dihampir semua negara yang menerapkan sistem perpajakan. Kepatuhan pajak dapat ditimbulkan dari berbagai aspek mulai dari aspek penegak hukum, struktur maupun tenaga kerja. Selain itu konsumsi pemerintah dalam penggunaan pajak menunjukkan penggunaan pajak yang transparan dan akuntabilitas atau tidak itu sangat mempengaruhi kepatuhan wajib pajak dalam membayar pajak. Dan dari aspek penegak hukum, harus diterapkannya sanksi yang tegas dan adil kepada setiap wajib pajak yang melanggar aturan perpajakan, penerapan sanksi tersebut diharapkan mampu membuat para wajib pajak lebih patuh dalam membayar pajak.

Demi terciptanya keteraturan dan ketertiban perpajakan, maka dibentuk suatu sanksi perpajakan bagi para pelanggar pajak. Sanksi tersebut juga berfungsi sebagai dasar bagi pemerintah untuk menentukan wajib pajak yang melanggar peraturan. Artinya, jika kewajiban perpajakan tidak dilaksanakan, maka akan ada konsekuensi hukum yang bisa terjadi. Pemerintah dalam hal ini Dirjen pajak membuat Undang-Undang tentang hal-hal yang berkaitan dengan perpajakan, termasuk sanksi yang diberikan jika para Wajib Pajak melanggar aturan tersebut.

Dalam rangka agar baik masyarakat wajib pajak maupun aparatur perpajakan mematuhi kewajiban-kewajiban, sekaligus sebagai perwujudan unsur pajak dapat dipaksakan sebagaimana didefinisikan, maka dituangkan ketentuan sanksi perpajakan, termasuk yang berkaitan dengan sanksi bagi wajib pajak (PKP) Pajak Pertambahan Nilai (PPN) dan Pajak Penjualan atas Barang Mewah (PPn BM) (Sutedi 2011 :221).

Dalam upaya meningkatkan kepatuhan pajak, perumus kebijakan sering kali terlalu mengandalkan pada sanksi. Perumus kebijakan mendisain sedemikian rupa dan mungkin begitu banyak sanksi, dengan tujuan agar kepatuhan meningkat (Rosdiana, 
H dan Edi, 2012:18).

Penegakan hukum di bidang perpajakan adalah tindakan yang dilakukan oleh pejabat terkait untuk menjamin supaya wajib pajak dan calon wajib pajak memenuhi ketentuan undang-undang perpajakan, seperti menyampaikan SPT, pembukuan, dan informasi lain yang relevan, serta membayar pajak pada waktunya.

Dengan adanya sanksi perpajakan yang lebih adil dan tegas mampu meningkatkan ketertiban dan kepatuhan wajib pajak dalam membayar pajak. Menurut Sutedi (2011 :227) "Kepatuhan perpajakan dapat didefinisikan sebagai suatu keadaan di mana wajib pajak memenuhi semua kewajiban perpajakan dan melaksanakan hak perpajakannya".

Menurut Sutedi (2011:227), ada 2 (dua) macam kepatuhan, yakni kepatuhan formal dan kepatuhan materiil. Kepatuhan formal adalah suatu keadaan dimana wajib pajak memenuhi kewajiban perpajakan secara formal sesuai dengan ketentuan formal dalam undang-undang perpajakan. Sedangkan kepatuhan materiil adalah suatu keadaan di mana wajib pajak secara substansif/hakikat memenuhi semua ketentuan materiil perpajakan, yakni sesuai isi dan jiwa undangundang perpajakan. Kepatuhan materiil meliputi juga kepatuhan formal.

Menurut Jatmiko (2006), Indikator Kepatuhan Wajib Pajak meliputi :

1. wajib pajak paham dan berusaha memahami UU Perpajakan

2. mengisi formulir pajak dengan benar

3. menghitung pajak dengan jumlah yang benar

4. membayar pajak tepat pada waktunya

Menurut Suandy (2002: 3), “wajib pajak adalah orang pribadi atau badan yang menurut ketentuan peraturan perundangundangan perpajakan ditentukan untuk melakukan kewajiban perpajakan, termasuk pemungut pajak atau pemotong pajak tertentu".
Kewajiban Wajib Pajak menurut Mardiasmo (2011: 56) sebagai berikut :

1. Mendaftarkan diri untuk mendapatkan NPWP.

2. Melaporkan usahanya untuk dikukuhkan sebagai PKP.

3. Menghitung dan membayar sendiri pajak dengan benar.

4. Mengisi dengan benar SPT (SPT diambil sendiri), dan memasukkan ke Kantor Pelayanan Pajak dalam batas waktu yang telah ditentukan.

5. Menyelenggarakan pembukuan/ pencatatan.

6. Jika diperiksa wajib :

a) Memperlihatkan dan atau meminjamkan buku atau catatan, dokumen yang menjadi dasarnya dan dokumen lain yang berhubungan dengan penghasilan yang diperoleh, kegiatan usaha, pekerjaan bebas Wajib Pajka, atau objek yang terutang pajak.

b) Memberikan kesempatan untuk memasuki tempat atau ruangan yang dipandang perlu dan memberi bantuan guna kelancaran pemeriksaan.

7. Apabila dalam waktu mengungkapkan pembukuan, pencatatan, atau dokumen serta keterangan yang diminta, Wajib Pajak terikat oleh suatu kewajiban untuk merahasiakan, maka kewajiban untuk merahasiakan ditiadakan oleh permintaan untuk keperluan pemeriksaan.

Menurut Ilyas, W dan Richard (2010 :201) mengatakan bahwa Kewajiban WP yang diatur dalam UU Perpajakan adalah:

1. Hak untuk mendapatkan pembinaan dan pengarahan dari fiskus.

2. Hak untuk membetulkan Surat Pemberitahuan.

3. Hak untuk memperpanjang waktu penyampaian Surat Pemberitahuan.

4. Hak memperoleh kembali kelebihan pembayaran pajak.

5. Hak mengajukan keberatan. 
6. Hak mengajukan banding.

7. Hak mengadukan pejabat yang membocorkan rahasia WP.

8. Hak mengajukan permohonan untuk mengangsur atau menunda pembayaran pajak.

9. Hak meminta keterangan mengenai koreksi dalam penerbitan ketetapan pajak.

10. Hak memberikan alasan tambahan.

11. Hak mengajukan gugatan.

12. Hak untuk menunda penagihan pajak.

13. Hak memperoleh imbalan bunga.

14. Hak mengajukan peninjauan kembali ke Mahkamah Agung.

15. Hak mengurangi penghasilan kena pajak dengan biaya yang telah dikeluarkan.

16. Hak pengurangan berupa Penghasilan Tidak Kena Pajak (PTKP).

17. Hak menggunakan norma penghitungan penghasilan neto.

18. Hak memperoleh fasilitas perpajakan.

19. Hak untuk melakukan pengkreditan Pajak Masukan terhadap Pajak Keluaran.

Hukum pajak adalah adalah keseluruhan dari peraturan-peraturan yang meliputi wewenang pemerintah untuk mengambil kekayaan seseorang yang menyerahkannya kembali kepada masyarakat melalui kas negara, sehingga hukum pajak tersebut merupakan hukum publik yang mengatur hubungan negara dan orang-orang atau badan-badan hukum yang berkewajiban membayar pajak (Sutedi, 2011 :6).

Hukum pajak materiil, memuat normanorma yang menerangkan keadaan, perbuatan, peristiwa hukum yang dikenakan pajak (subyek), berapa besar pajak yang dikenakan, segala sesuatu tentang timbul dan hapusnya hutang pajak, dan hubugan hukum antara pemerintah dan wajib pajak (Waluyo dan Wirawan, 2002:10).

Menurut Tjahjono Ahmad dan Husein (2005: 10), hukum pajak formal mengatur tentang cara-cara mengimplementasikan hukum material menjadi suatu kenyataan. Termasuk didalamnya cara-cara penyelenggaraan mengenai penetapan suatu hutang pajak, pengawasan oleh pemerintah terhadap penyelenggaraannya, kewajiban para wajib pajak baik sebelum maupun sesudah diterimanya surat ketetapan pajak, kewajiban pihak ketiga dan prosedur dalam pemungutannya.

Menurut Keputusan Menteri Keuangan No : 544/KMK.04/2000) tanggal 22 Desember 2000 tentang kriteria wajib pajak patuh adalah sebagai berikut :

a. Tepat waktu dalam menyampaikan surat pemberitahuan untuk semua jenis pajak dalam 2 (dua) tahun terakhir.

b. Tidak mempunyai tunggakan pajak untuk semua jenis pajak, kecuali telah memperoleh izin untuk menganggur atau menunda pembayaran pajak.

c. Tidak pernah dijatuhi hukuman karena melakukan tindak pidana di bidang perpajakan dlam jangka waktu 10 (sepuluh) tahun terakhir.

d. Dalam 2 (dua) tahun pajak terakhir wajib pajak:

1) Menyelenggarakan pembukuan sebagaimana dimaksud dalam Pasal 28 UU KUP, dan

2) Dalam hal terhadap wajib pajak pernah dilakukan pemeriksaan, koreksi pada pemeriksan yang terakhir untuk masing-masing jenis pajak yang terutang paling banyak $5 \%$.

"Sanksi perpajakan merupakan jaminan bahwa ketentuan peraturan perundangundangan perpajakan (norma perpajakan) akan dituruti/ditaati/dipatuhi. Atau bisa Wajib Pajak tidak melanggar norma perpajakan" (Mardiasmo, 2011 :59). Sanksi pajak merupakan suatu alat pencegah bagi wajib pajak agar tidak melanggar ketentuan perpajakan.

Menurut Purwono (2010:68) berdasarkan jenisnya, "sanksi di bidang perpajakan dapat dikelompokkan menjadi dua kategori 
yaitu sanksi administrasi dan sanksi pidana".

Sanksi administrasi merupakan pembayaran kerugian terhadap negara yang bisa berupa denda administrasi, bunga, atau kenaikan pajak yang terutang. Sanksi administrasi ditekankan kepada pelanggaranpelanggaran administrasi perpajakan yang tidak mengarah kepada tindak pidana perpajakan (Purwono, $2010: 68$ ).

Sanksi pidana merupakan upaya terakhir dari pemerintah agar norma perpajakan benar-benar dipatuhi. Sanksi pidana ini bisa timbul karena adanya tindak pidana pelanggaran yaitu tindak pidana yang mengandung unsur ketidaksengajaan atau kealpaan, atau dikarenakan adanya tindak pidana kejahatan yaitu tindak pidana yang mengandung unsur kesengajaan atau kelalaian/pengabaian. Sedangkan ancaman sanksi pidana dapat berupa denda pidana, pidana kurungan, atau pidana penjara (Purwono, 2010:68).

Menurut Arum (2012), Indikator Sanksi Perpajakan meliputi :

a. Sanksi pajak sangat diperlukan agar tercipta kedisiplinan wajib pajak dalam memenuhi kewajiban perpajakan.

b. Pengenaan sanksi harus dilaksanakan dengan tegas kepada semua wajib pajak yang melakukan pelanggaran.

c. Sanksi yang diberikan kepada wajib pajak harus sesuai dengan besar kecilnya pelanggaran yang sudah dilakukan.

d. Penerapan sanksi pajak harus sesuai dengan ketentuan dan peraturan yang berlaku.

\section{METODE PENELITIAN}

\section{Tempat Penelitian}

Dalam penelitian ini penulis mengambil tempat pada KPP Pratama Madiun yang berlokasi di jalan D. I Panjaitan No.04 Madiun. Subjek dalam penelitian ini adalah wajib pajak orang pribadi patuh menyampai kan SPT dengan tepat waktu di KPP Pratama Madiun.

\section{Metode Penelitian}

Dalam menyelesaikan penelitian ini perlu digunakan cara atau metode yang tepat di pertanggung jawabkan secara ilmiah. Penelitian ini menggunakan penelitian kuantitatif, dengan demikian "metode kuantitatif dapat diartikan sebagai metode penelitian yang berlandaskan pada filsafat positivisme, digunakan untuk meneliti pada populasi atau sampel tertentu, pengumpulan data menggunakan instrumen penelitian, analisis data bersifat kuantitatif/statistik, dengan tujuan untuk menguji hipotesis yang telah ditetapkan" (Sugiyono, 2014: 11).

\section{Desain Penelitian}

Desain penelitian yang digunakan dalam penelitian ini menggunakan hubungan kausal. Menurut (Sugiyono, 2014: 62) "hubungan kausal adalah hubungan yang bersifat sebab akibat". Dalam penelitian ini menjelaskan pengaruh kausal antara variabel melalui pengajuan hipotesis dilakukan untuk mengetahui ada tidaknya pengaruh sanksi perpajakan terhadap terhadap kepatuhan wajib pajak orang pribadi di KPP Pratama Madiun.

Agar lebih jelas desain penelitiannya digambarkan sebagai berikut :

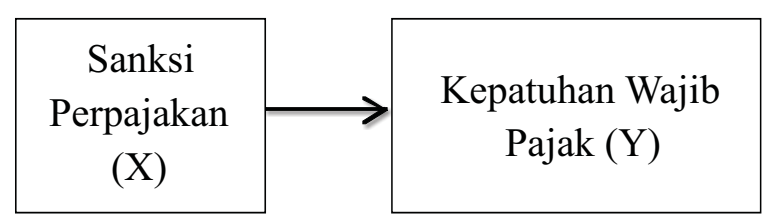

Gambar 3.1 Desain Penelitian

Dari gambar diatas dapat diketahui bahwa penelitian ini bertujuan untuk menguji pengaruh sanksi perpajakan terhadap kepatuhan wajib pajak. Variabel bebas (X) adalah variabel yang tidak dipengaruhi oleh variabel lainnya, dalam penelitian ini yaitu 
sanksi perpajakan $(\mathrm{X})$, yang secara parsial atau sendiri-sendiri berpengaruh terhadap variabel terikat(Y) kepatuhan wajib pajak.

\section{Populasi}

Populasi dalam penelitian ini adalah wajib pajak orang pribadi yang berada di kota Madiun tidak termasuk yang berada di kabupaten Madiun, yang terdaftar sebagai karyawan pada KPP Pratama Madiun di Tahun 2016 sejumlah 43.651 wajib pajak.

\section{Sampel}

Dalam hal ini yang menjadi sampel dalam penelitian adalah wajib pajak orang pribadi yang terdaftar sebagai karyawan di KPP Pratama Madiun di tahun 2016. Sampel dalam penelitian ini sejumlah 385 wajib pajak.

\section{Teknik Pengambilan Sampel}

Pengambilan sampel dilakukan dengan teknik Sampling Insidental. "Sampel Insidental adalah teknik penentuan sampel berdasarkan kebetulan, yaitu siapa saja yang secara kebetulan/insidental bertemu dengan peneliti dapat digunakan sebagai sampel, bila dipandang orang yang kebetulan ditemui itu cocok sebagai sumber data" (Sugiyono, 2014:126).

Dalam penelitian ini teknik pengumpulan data yang digunakan adalah

a) Observasi

"Observasi atau pengamatan langsung adalah kegiatan pengumpulan data dengan melakukan penelitian langsung terhadap kondisi lingkungan objek penelitian yang mendukung kegiatan penelitian, sehingga didapat gambaran secara jelas tentang kondisi objek penelitian tersebut" (Siregar, 2014: 42). Metode observasi digunakan dalam penelitian ini adalah untuk mengetahui situasi dan kondisi yang terjadi ditempat penelitian. Alat yang digunakan berupa buku catatan.

b) Metode Kuesioner

"Kuesioner merupakan instrumen untuk pengumpulan data, dimana partisipan atau responden mengisi pertanyaan atau pernyataan kemudian setelah diisi dengan lengkap mengembalikan kepada peneliti" (Sugiyono, 2014 :192). Dalam penelitian ini kuesioner yang diberikan kepada wajib pajak orang pribadi yang menyampaikan SPT di KPP Pratama Madiun sebagai responden yang berhubungan dengan materi pembahasan penyusunan penelitian yang berkaitan dengan sanksi perpajakan terhadap kepatuhan wajib pajak. Kuesioner ini berbentuk pernyataan yang disertai alternatif jawaban dan responden tinggal memilih salah satu dari alternatif jawaban tersebut.

Dalam penelitian ini digunakan angket untuk mengetahui respon wajib pajak terhadap sanksi perpajakan dan kepatuhan wajib pajak orang pribadi. Jumlah pernyataan yang digunakan dalam angket ini sebanyak 20 yakni 10 pernyataan untuk variabel Sanksi Perpajakan dan 10 pernyataan untuk variabel Kepatuhan.

c) Metode dokumentasi

Menurut Arikunto (2013 :274), "Dokumentasi adalah mencari data, mengenai hal - hal atau variabel yang berupa catatan, transkrip, buku, surat kabar, majalah, prasasti, notulen rapat, legger, agenda, dan sebagainya". Pengumpulan data dengan metode dokumentasi dilakukan dengan mengambil data wajib pajak orang pribadi yang terdaftar di KPP Pratama Madiun pada tahun 2016 .

\section{Instrumen Penelitian}

"Instrumen penelitian adalah suatu alat yang digunakan untuk mengukur fenomena alam maupun sosial yang diamati" (Sugiyono 
2014 :148). Instrumen penelitian yang digunakan dalam penelitian ini yaitu dengan menggunakan kuesioner atau angket.

Pada penelitian ini yang digunakan adalah berupa pemberian skor berdasarkan skala likert. Menurut Sugiyono (2014:136) "Skala likert digunakan untuk mengukur sikap, pendapat, dan persepsi seseorang atau sekelompok orang tentang fenomena sosial". Dalam penelitian ini skala likert digunakan agar mempermudah responden dalam menjawab pertanyaan, kemudian responden menjawab pertanyaan sesuai dengan kode yang ada dalam kuesioner. Jawaban dari responden yang tercantum dalam kuesioner bersifat tertutup dan dijamin kerahasiaannya.

\section{Uji Prasarat atau Instrumen}

\section{a. Uji Validitas}

"Validitas atau kesahihan adalah menunjukkan sejauh mana suatu alat ukur mampu mengukur apa yang ingin diukur" (siregar, 2012: 162). Dalam uji validitas digunakan korelasi product moment. Uji validitas bertujuan untuk mengetahui apakah item-item pertanyaan yang diuji dapat digunakan untuk mengukur keadaan responden yang sebenarnya.

b. Uji Reliabilitas

Reliabilitas adalah "sesuatu instrument cukup dipercaya untuk digunakan sebagai alat pengumpul data karena istrumen tersebut sudah baik“" (Arikunto, 2013: 221). Uji reliabilitas yang digunakan dalam penelitian ini menggunakan metode Cronbach Alpha.

\section{Uji Asumsi Klasik}

Uji Asumsi Klasik dalam penelitian ini menggunakan Uji Normalitas. "Uji Normalitas bertujuan untuk menguji apakah dalam model regresi variabel pengganggu atau residual memiliki distribusi normal" (Gozali, 2011 :160). Menurut Priyatno (2013 :56) syarat dalam analisis parametrik yaitu distribusi data harus normal. Pengujian menggunakan uji Kolmogorov-Smirnov (Analisis Explore) untuk mengetahui apakah distribusi data pada tiap-tiap variabel normal atau tidak. Kriteria pengambilan keputusan yaitu jika signifikansi $>0,05$ maka data distribusi normal dan jika signifikansi $<0,05$ maka data tidak berdistribusi normal.

Dalam penelitian pengaruh Sanksi Perpajakan terhadap Kepatuhan Wajib Pajak, analisis yang digunakan adalah dengan menggunakan regresi linier sederhana.

Dalam analisis regeresi, untuk mencari pengaruh digunakan uji t. Menurut Siregar (2014 :195) Uji t digunakan untuk mengetahui pernyataan atau dugaan yang dihipotesiskan oleh si peneliti.

\section{HASIL DAN PEMBAHASAN Statistik Deskriptif}

Dideskripsikan bahwa Sanksi Perpajakan, dengan jumlah data (N) sebanyak 385 Wajib Pajak mempunyai deskripsi data sebagai berikut: (a) Jumlah skor total sebesar 14.450; (b) Nilai rata-rata hitung (mean) sebasar 37,53; (c) Median sebesar 38,00; (d) Modus sebesar 41,00; (e) Standar deviasi sebesar 5.084; (f) Nilai minimum sebesar 19; (g) Nilai maximum sebesar 50.

Hasil analisis deskriptif sanksi perpajakan yang diolah kuisioner 385 wajib pajak, yang berada di atas nilai ratarata sebanyak 209 wajib pajak atau $54 \%$ sedangkan yang dibawah rata-rata sebanyak 176 wajib pajak atau 46\%. Artinya wajib pajak orang pribadi di KPP Pratama Madiun setuju dengan adanya sanksi perpajakan.

Dideskripsikan bahwa kepatuhan, dengan jumlah data $(\mathrm{N})$ sebanyak 385 Wajib Pajak mempunyai deskripsi data sebagai berikut: (a) Jumlah skor total sebesar 14.412; (b) Nilai rata-rata hitung (mean) sebasar 37,43; (c) Median sebesar 38,00; (d) Modus sebesar 38: (e) Standar deviasi sebesar 5.141; 
(f) Nilai minimum sebesar 20; (g) Nilai maximum sebesar 49 .

Hasil analisis deskriptif sanksi perpajakan yang diolah kuisioner 385 wajib pajak, yang berada di atas nilai rata-rata sebanyak 236 wajib pajak atau $61 \%$ sedangkan yang dibawah rata-rata sebanyak 149 wajib pajak atau 39\%. Artinya wajib pajak orang pribadi di KPP Pratama Madiun patuh dalam membayar pajak.

\section{Hasil Uji Validitas}

Hasil dari uji validitas angket Sanksi Perpajakan di uji kepada Wajib Pajak orang pribadi yang berjumlah 385 orang. Dari 10 soal Sanksi Perpajakan yang di uji hasilnya semua valid. Hasil dari uji validitas angket Kepatuhan di uji kepada Wajib Pajak orang pribadi yang berjumlah 385 orang. Dari 10 soal Sanksi Perpajakan yang di uji hasilnya semua valid (koefisien di atas 0,098). Sehingga data tersebut dapat digunakan semua untuk keperluan analisis penelitian.

\section{Hasil Uji Reliabilitas}

Uji Reliabilitas pada penelitian ini dilakukan dengan menggunakan rumus alpha cronbach. Siregar (2012: 175), "kriteria suatu instrumen penelitian dikatakan reliabel dengan menggunakan teknik Alpha Cronbach bila koefisien reliabilitas $\left(\mathrm{r}_{11}\right)>$ 0,6". Hasil uji reliabilitas variabel Sanksi Perpajakan dan Kepatuhan masing-masing adalah 0,798 dan 0,787 maka semua dinyatakan reliabel.

\section{Hasil Uji Asumsi Klasik}

Uji Normalitas bertujuan untuk menguji apakah dalam model regresi variabel pengganggu atau residu memiliki distribusi normal. Apabila data berdistribusi normal, maka dapat digunakan uji statistik berjenis parametrik. Syarat analisis parametrik yaitu distribusi data harus normal. Pengujian menggunakan uji Kolmogorov-Smirnov
(Analisis Explore) untuk mengetahui apakah distribusi data pada tiap-tiap variabel normal atau tidak. hasil uji normalitas diketahui bahwa nilai Assymp Sig sebesar 0,631 lebih besar dari 0,05, dengan demikian dapat disimpulkan bahwa data yang akan dianalisis terdistribusi normal.

\section{Hasil Uji Regresi}

Hasil dari perhitungan Regresi Linier Sederhana diatas dapat dibuat persamaan garis regresi sebagai berikut : $\mathrm{Y}=6.839+$ 0.815X. Artinya apabila Sanksi Perpajakan meningkat sebanyak 1\%, maka kepatuhan akan meningkat sebesar 0,815 , apabila faktor lain dianggap tetap.

\section{Hasil Uji T}

Dari hasil perhitungan uji t diperoleh nilai $t_{\text {hitung }}$ sebesar 26,664 sedangkan nilai $t_{\text {tabel }}$ dengan jumlah responden 385 dan probabilitas 0,05 sebesar 1.966 . Hal ini berarti $\mathrm{t}_{\text {hitung }} \geq \mathrm{t}_{\text {tabel }}(26,664 \geq 1,966)$. Sehingga dari hasil uji t diatas dapat disimpulkan bahwa $\mathrm{Ha}$ diterima, Ho ditolak, artinya bahwa ada pengaruh antara Sanksi Perpajakan Terhadap Kepatuhan Wajib Orang Pribadi pada KPP Pratama Madiun.

\section{PENUTUP}

\section{Simpulan}

Berdasarkan hasil analisis data pada pembahasan bab sebelumnya, maka dapat diambil kesimpulan sebagai berikut:

1. Wajib pajak orang pribadi yang terdaftar di KPP Pratama Madiun setuju dengan adanya sanksi perpajakan. Hal ini dapat dilihat dari hasil pengisian kuesioner yang telah dilakukan oleh wajib pajak orang pribadi di KPP Pratama Madiun. Dari hasil jawaban responden sebanyak 385 wajib pajak, yang berada di atas nilai ratarata sebanyak 209 wajib pajak atau 54\%, sedangkan yang dibawah rata-rata sebanyak 176 wajib pajak atau $46 \%$. 
2. Kepatuhan Wajib Pajak orang pribadi yang terdaftar di KPP Pratama Madiun sangat baik. Hal ini dapat dilihat dari hasil pengisian kuesioner yang telah dilakukan oleh wajib pajak orang pribadi di KPP Pratama Madiun. Dari hasil jawaban responden sebanyak 385 wajib pajak, yang berada di atas nilai rata-rata sebanyak 236 wajib pajak atau $61 \%$ sedangkan yang di bawah rata-rata sebanyak 149 wajib pajak atau $39 \%$

3. Sanksi Perpajakan secara parsial berpengaruh signifikan terhadap kepatuhan wajib pajak orang pribadi yang terdaftar di KPP Pratama Madiun

a) Uji Regresi, yaitu $Y=6.839+0.815 X$. Artinya apabila Sanksi Perpajakan meningkat sebanyak 1\%, maka Kepatuhan Wajib Pajak akan meningkat sebesar 0.347, apabila faktor lain dianggap tetap.

b) Uji T, yaitu $T_{\text {hitung }}$ sebesar 26,664, sedangkan $T_{\text {tabel }}$ sebesar 1,966. Hal ini berarti $T_{\text {hitung }} \geq T_{\text {tabel }}(26,664 \geq 1,966)$. Artinya ada pengaruh antara Sanksi Perpajakan terhadap Kepatuhan Wajib Pajak Orang Pribadi di KPP Pratama Madiun.

Berdasarkan penelitian yang telah dilakukan, dapat diinteprestasikan bahwa apabila Dirjen Pajak melakukan sanksi perpajakan dengan tegas maka akan dapat meningkatkan Kepatuhan Wajib Pajak, hal tersebut dikarenakan dengan adanya pengenaan sanksi pajak dapat meningkatkan kesadaran akan hak dan kewajiban wajib pajak serta dapat meningkatkan kepatuhan wajib pajak dalam perpajakan. Wajib pajak akan mematuhi pembayaran pajak bila memandang sanksi denda akan lebih banyak merugikannya. Semakin banyak sisa tunggakan pajak yang harus dibayar wajib pajak, maka akan semakin berat bagi wajib pajak untuk melunasinya.

\section{Saran}

Berdasarkan hasil penelitian yang telah diuraikan dalam kesimpulan di atas, maka dalam penelitian ini disampaikan beberapa saran sebagai berikut:

1. Bagi Kantor Pelayanan Pajak Pratama Madiun

Berdasarkan dari hasil penelitian bahwa sanksi perpajakan terbukti secara parsial berpengaruh signifikan terhadap kepatuhan wajib pajak orang pribadi yang terdaftar di KPP Pratama Madiun. Dengan demikian KPP Pratama Madiun harus melakukan pengenaan sanksi pajak yang tegas bagi yang melanggar kewajibannya sebagai wajib pajak, dalam rangka pembinaan wajib pajak dalam menyampaikan dan membayar pajak. Sehingga dapat memberikan kontribusi kepada Negara berupa peningkatan pendapatan pajak. Selain itu sanksi perpajakan yang dilakukan harus sesuai dengan besar kecilnya pelanggaran yang dilakukan wajib pajak, serta sanksi pajak yang diterapkan harus adil pada setiap pelaku pelanggar pajak tanpa membedakan siapapun dia (termasuk para pejabat publik maupun keluarganya) yang melakukan pelanggaran pajak.

2. Bagi Civitas Akademika

Bagi peneliti yang tertarik ingin melakukan penelitian selanjutnya khususnya tentang pengaruh sanksi perpajakan terhadap kepatuhan wajib pajak orang pribadi, peneliti dapat menambahkan variabel diluar variabel sanksi perpajakan yang merupakan variabel pendukung. Misalnya adalah variabel penyuluhan, kesadaran wajib pajak, motivasi, pengetahuan dan kualitas pelayanan. Agar memperoleh hasil yang lebih bervariatif yang dapat menggambarkan hal-hal apa saja yang dapat berpengaruh terhadap kepatuhan membayar pajak. 


\section{Bagi Masyarakat}

Diharapkan dengan adanya penelitian ini dapat digunakan sebagai bahan referensi guna menambah wawasan dan pengetahuan dibidang perpajakan. Sehingga pada akhirnya akan meningkatkan kepatuhan wajib pajak.

\section{DAFTAR PUSTAKA}

Arikunto, S. 2013. Prosedur Penelitian Suatu Pendekatan Praktik. Jakarta: Rineka Cipta.

Arum, Harjanti. (2012). Pengaruh Kesadaran Wajib Pajak, Pelayanan Fiskus Dan Sanksi Pajak Terhadap Kepatuhan Wajib Pajak Orang Pribadi Yang Melakukan Kegiatan Usaha Dan Pekerjaan Bebas (Studi di Wilayah KPP Pratama Cilacap). Skripsi tidak diterbitkan. Semarang: Program Studi Pendidikan Ekonomi Universitas Diponegoro.

Diana, A., dan Setiawati, L. 2009. Perpajakan Indonesia konsep aplikasi dan penuntun praktis. Yogyakarta: Andi Offset.

Fitriandi, Primandita. dkk. 2006. Kompilasi Undang-Undang Perpajakan. Jakarta: Salemba Empat.

Ghozali, I. 2011. Aplikasi Analisis Multivariate dengan Program IBM SPSS 19. Semarang: Badan Penerbit Universitas Diponegoro.

Ilyas, Wirawan dan Richard. 2010. Hukum Pajak. Jakarta: Salemba Empat.

Imam, Z. 2014. Pengaruh Sanksi Perpajakan, Kualitas Pelayanan Dan Penerapan System Administrasi Perpajkan Modern Terhadap Kepatuhan Wajib Pajak,
Jurnal Ilmiah PROGRESSIF, Vol.11, No.31 (http://untag-banyuwangi.ac.id diakses 2 April 2016).

Jatmiko, A. (2006). Pengaruh Sikap Wajib Pajak Pada Pelaksanaan Sanksi Denda, Pelayanan Fiskus Dan Kesadaran Perpajakan Terhadap Kepatuhan Wajib Pajak (Studi Empiris Terhadap Wajib Pajak Orang Pribadi di Kota Semarang). Tesis tidak diterbitkan. Semarang: Program Studi Magister Sains Akuntansi Universitas Diponegoro.

Keputusan Menteri Keuangan Republik Indonesia Pasal 1 Th. 2000. Tentang Kriteria Wajib Pajak Patuh, (http://www.jdih.kemenkeu.go.id, Diunduh 19 Mei 2016).

Mardiasmo, 2011. Perpajakan Edisi Revisi. Yogyakarta: Andi Offset.

Ngadiman, dan Daniel, H. 2015. Pengaruh Sunset Policy, Tax Amnesty, Dan Sanksi Pajak Terhadap Kepatuhan Wajib Pajak, Jurnal Akuntansi, Volume XIX, No. 02 (http//journal.tarumanagara.ac.id diakses 2 April 2016).

Noor, J. 2011. Metode Penelitian: Skripsi, Tesis, Disertasi, Dan Karya Ilmiah. Jakarta: Prenada Media Group.

Pudyatmoko, Y. S. 2002. Pengantar Hukum Pajak. Yogyakarta:Andi Offset.

Purwono, H. 2010. Dasar-Dasar Perpajakan \& Akuntansi Pajak. Jakarta: Penerbit Erlangga.

Priyatno, D. 2013. SPSS Analisis Korelasi, Regresi dan Multivarate. Yogyakarta: Gava Media.

Resmi, Siti.2005. Perpajakan: Teori Dan Kasus. Jakarta: Salemba Empat. 
Rosdiana, Haula dan Edi. 2012. Pengantar Ilmu Perpajakan. Jakarta: PT RajaGrafindo Persada.

Siregar, S. 2014. Statistik Parameirik Untuk Penelitian Kuantitatif Dilengkapi Dengan Perhitungan Manual Dan Aplikasi Spss Versi 17. Jakarta: Bumi Aksara.

Siregar, Sofian. 2012. Statistika Deskriptif untuk Penelitian. Jakarta: Rajawali Pers.

Suandy, Erly. 2002. Perpajakan. Jakarta: Salemba Empat.

Sugiyono. 2010. Metode Penelitian Bisnis. Bandung: Alfabeta.

Sugiyono. 2014. Metode Penelitian Kombinasi (Mixed Methods). Bandung. Alfabeta.

Sutedi, A. 2011. Hukum Pajak. Jakarta: Sinar Grafika.

Tahar, A \& Wilie Sandy. 2012. Pengaruh Persepsi Wajib Pajak Atas Pelayanan
Kpp, Sanksi Perpajakan Dan Pengetahuan Atas Penghasilan Kena Pajak Terhadap Kepatuhan Wajib Pajak, Jurnal Akuntansi Dan Investasi Vol. 12 No. 02 (http//journal.umy.ac.id diakses 19 Mei2016).

Tiraada, T. 2013. Kesadaran Perpajakan, Sanksi Pajak, Sikap Fiskus Terhadap Kepatuhan Wpop Di Kabupaten Minahasa Selatan, Jurnal Emba, Vol.1 No.3 (Http//Ejournal.Unsrat.Ac.Id Diakses 2 April 2016).

Tjahjono, A dan Husein, M. 2005. Perpajakan. Yogyakarta: Unit Penerbit dan Percetakan Akademi Manajemen Perusahaan YKPN.

Waluyo. 2013. Perpajakan Indonesia. Jakarta: Salemba Empat.

Waluyo. 2010. Perpajakan Indonesia. Jakarta: Salemba Empat.

Waluyo, dan Wirawan. 2002. Perpajakan Indonesia. Jakarta: Salemba Empat. 